ZOOLOGIA 28 (4): 513-516, August, 2011

doi: $10.1590 /$ S1984-46702011000400013

\title{
A new species of Sisimitalia (Hemiptera: Cicadellidae: Cicadellinae) with a key to the species of the genus
}

\author{
Rodney Ramiro Cavichioli
}

Departamento de Zoologia, Universidade Federal do Paraná. Caixa Postal 19020, 81531-980 Curitiba, PR, Brazil. E-mail: cavich@ufpr.br

\begin{abstract}
Sisimitalia henriquei sp. nov. is described and illustrated based on specimens collected in Boquete, Panama. This new species can be easily distinguished from other congeneric species based on the external coloration and shape of the paraphyses. A key to the species of the genus is also presented.

KEY WORDS. Cicadellini; description; distribution; Neotropical Region; Sisimitalia henriquei sp. nov.
\end{abstract}

Sisimitalia was described by Young (1977: 756) in his revision of the New World Cicadellini. Originally, the genus included three species: S. infulata (Fowler, 1900), S. rubricollis (Fowler, 1900), and S. vulnerata (Signoret, 1855) (type-species). Sisimitalia is distributed from Mexico to Colombia (Young 1977, Oman et al. 1990, McKamey 2007) and can be recognized by the following features: 1) head moderately produced anteriorly; 2 ) pronotal width greater than transocular width of head in dorsal view; 3) lateral margins of pronotum convergent anteriorly in dorsal view; 4) forewings with veins indistinct, except at the apex, with three anteapical cells, of which one or two innermost cells are open basally; 5) styles with a lateral lobe approximately at mid-length, apex convex or truncate; 6) short-stalked paraphyses with rami slender and elongate; and 7) membrane of female genital chamber (internal sternite VIII) with sclerotized areas (absent in some specimens). In the present paper, a new species, $S$. henriquei (from Boquete, Panama), is described and illustrated. Along with the species description, a modified version of Young's (1977: 759) key to Sisimitalia species is also provided.

\section{MATERIAL AND METHODS}

The specimens studied herein are deposited in the Coleção Entomológica Pe. Jesus Santiago Moure, Departamento de Zoologia, Universidade Federal do Paraná, Curitiba (DZUP). Terminology follows mainly follows Young $(1968,1977)$, except for head structures, which follows Hamilton (1981) and Mejdalani (1998). Terminology for the leg chaetotaxy follows RAKITOv (1997) and for the female genitalia, Nielson (1965). The male and female genitalia were prepared according to OMAN (1949) and stored in microvials with glycerin. In quotations of label data, a reversed virgule $(\backslash)$ separates lines on the label.

\section{Sisimitalia henriquei Cavichioli, sp. nov.}

Figs 1-13

Diagnosis. Medium-sized cicadellines; general coloration red; crown moderately produced, with anterior margin broadly rounded; pronotum larger than transocular width, lateral margins convergent; male pygofer without processes; aedeagus short and decurved; paraphyses symmetrical with rami slender and with two short rami at base.

Description. Length, male $9.8-10.0 \mathrm{~mm}$; female $10.2 \mathrm{~mm}$.

Head and thorax. Crown (Fig. 1) moderately produced; median length of crown slightly more than one-half interocular width and slightly more than one-third transocular width; anterior margin broadly rounded in dorsal view, without median fovea and without sculpturing or setae, but with distinct concavity between ocelli; without carina at transition from crown to face. Frontogenal suture extending onto crown and attaining ocelli. Ocelli located before imaginary line between anterior angles of eyes, each equidistant from adjacent eye angle and median line of crown. Antennal ledges slightly protuberant in dorsal view; in lateral view, convex and oblique. Antennae longer than length of crown and pronotum combined. Frons slightly convex, median area flattened and smooth; muscular impressions distinct. Epistomal suture incomplete for a short median distance. Clypeus, in lateral view, continuing profile of frons, except for nearly horizontal apex; apical margin rounded; face not pubescent. Pronotum width greater than transocular width (Fig. 1); lateral margins convergent anteriorly; median length approximately six-tenths transhumeral width; dorsopleural carina complete; posterior margin with slight median reentrance; disk smooth, not pubescent. Mesonotum smooth, not striate behind transverse sulcus. Forewings (Fig. 1) with distal membrane; veins indistinct ex- 

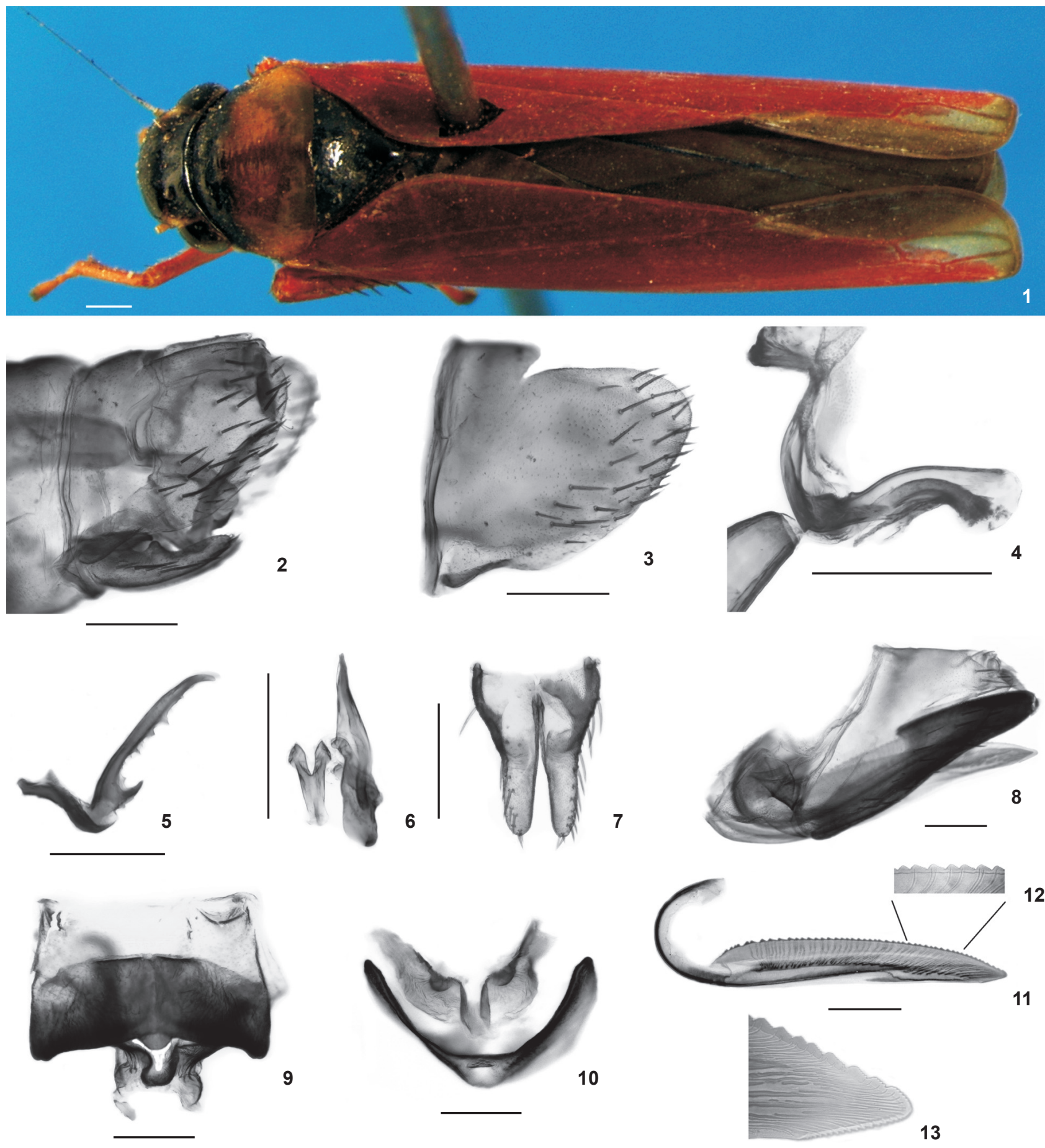

Figures 1-13. Sisimitalia henriquei sp. nov.: (1) male holotype, dorsal habitus; (2-7) male genitalia: (2) genital capsule, lateral view; (3) pygofer, lateral view; (4) aedeagus, lateral view; (5) paraphyses, lateral view; (6) style and connective, dorsal view; (7) subgenital plates, ventral view; (8-13) female genitalia; (8) pygofer and ovipositor, lateral view; (9) sternite VII and internal sternite VIII, ventral view; (10) sternite VII and internal sternite VIII, posterior view; (11-12) second valvula of the ovipositor and its teeth (inset), lateral view; (13) apex of the second valvula. Scale bar $=0.5 \mathrm{~mm}$. 
cept at apex; with four apical cells, base of third cell more apical than base of fourth; with three anteapical cells, of which the two innermost are open basally; texture slightly coriaceous, without sculpturing; length exceeding apex of ovipositor at rest. Hindwings with vein $\mathrm{R}_{2+3}$ incomplete. Hindlegs with femoral formula $2: 1: 1$; hindtibiae with anterodorsal row of macrosetae with short intercalary setae (approximately four in between each pair of macrosetae); first tarsomere longer than length of two distal tarsomeres combined; plantar surface with two parallel rows of short setae.

Coloration. Head (Fig. 1) black; genae and clypeus castaneous at apex; other small castaneous marks may be present on head. Thorax and legs (Fig. 1) reddish-yellow ventrally. Pronotum castaneous with anterior margin black. Mesonotum black. Forewings (Fig. 1) red with smoky membrane.

Male genitalia. Pygofer (Figs 2 and 3) slightly produced, apex rounded, without processes; macrosetae distributed from basal third to apex; valve almost linear, slightly broadened. Subgenital plates (Figs 2 and 7), in lateral view, not extending posteriorly beyond pygofer apex, in ventral view, subtriangular, with few uniseriate macrosetae. Styles (Fig. 6) broad, extending slightly beyond apex of connective, with lateral lobe near mid-length of shaft, apically truncate. Connective (Fig. 6) Yshaped. Aedeagus short (Fig. 4), without processes, shaft decurved and slightly enlarged apically. Paraphyses (Fig. 5) short-stalked, with rami slender and jagged ventrally, with two short rami at base.

Female genitalia. Pygofer (Fig. 8) moderately produced; posterior margin acute; macrosetae distributed along ventroapical margin. Sternite VII (Fig. 9) short; posterior margin with median and lateral lobes. Internal sternite VIII (Figs 9 and 10) sclerotized with two lateral lobes. Second valvula of ovipositor (Figs 11-13) with dorsal margin of expanded area slightly convex, bearing approximately 48 teeth; each tooth subtriangular and with denticles (Fig. 12); ventral prominence slightly visible; preapical area (Fig. 13) with denticles on dorsal and ventral margins; apex acute.

Type material. Holotype male labeled: "21, 23, 25-vii1997 Finca Lerida \Alto Quel, Boquete, Chiriqui \Panamá, 1900$2200 \mathrm{~m} \backslash$ Mielke \& Casagrande leg" (DZUP). Paratypes. One male and one female, same data as holotype (DZUP).

Distribution. Specimens of the new species were collected in Boquete, Panama, between 1900-2200 m a.s.l.

Etymology. This species is dedicated to my son Henrique Coelho Netto.

Remarks. Sisimitalia henriquei sp. nov. is herein assigned to Sisimitalia based on features 1-7 specified in the introduction. The new species keys out at couplet 147 of Young's (1977) key to the New World genera of Cicadellini. Based on comparisons of images provided by the project "Digital imaging of world genera of the sharpshooters" (WILson et al. 2009), S. henriquei sp. nov. closely resembles $S$. rubricollis in the external morphology. The styles (Fig. 6) of S. henriquei sp. nov. are similar to those of S. rubricollis, whereas the aedeagus (Fig. 4) resembles that of S. infulata. Sisimitalia henriquei sp. nov. can be easily distinguished from other Sisimitalia species by the coloration (Fig. 1) and shape of the paraphyses (Fig. 5).

\section{Key to species of Sisimitalia}

1 . Forewings uniformly colored 2

1 '. Forewings not as above.... 3

2. Forewings black S. rubricollis (Fowler)

2'. Forewings red S. henriquei sp. nov.

3. Aedeagus with shaft curved caudoventrally, subgenital plates with uniseriate macrosetae; posterior margin of female sternite VII truncate. S. infulata (Fowler)

3'. Aedeagus with shaft not curved, subgenital plates with numerous microsetae, without macrosetae; posterior margin of female sternite VII produced and tapered ......... S. vulnerata (Signoret)

\section{ACKNOWLEDGEMENTS}

I thank Olaf H.H. Mielke and Mirna M. Casagrande for collecting the specimens studied herein. Preliminary versions of this manuscript benefited from the useful comments of Olivia E. de Souza. This research was partially funded by the Conselho Nacional de Desenvolvimento Científico e Tecnológico (CNPq, research grant 303127/2010-4). This paper is the contribution number 1853 of the Departamento de Zoologia, Universidade Federal do Paraná.

\section{LITERATURE CITED}

Hamilton, K.G.A. 1981. Morphology and evolution of the rhynchotan head (Insecta: Hemiptera, Homoptera). Canadian Entomologist 113: 953-974.

Mejdalani, G. 1998. Morfologia externa dos Cicadellinae (Homoptera, Cicadellidae): comparação entre Versigonalia ruficauda (Walker) (Cicadellini) e Tretogonia cribrata Melichar (Proconiini), com notas sobre outras espécies e análise da terminologia. Revista Brasileira de Zoologia 15: 451-544.

McKamey, S. 2007. Taxonomic catalogue of the leafhoppers (Membracoidea). Part 1. Cicadellinae. Memoirs of the American Entomological Institute 78: 1-394.

Nielson, M.W. 1965. A revision of the genus Cuerna (Homoptera, Cicadellidae). Technical Bulletin of the United States Department of Agriculture 1318: 1-48.

Oman, P.W. 1949. The Nearctic leafhoppers (Homoptera: Cicadellidae). A generic classification and check list. Memoirs of the Entomological Society of Washington 3: 1-253.

Oman, P.W.; W.J. Knight \& M.W. Nielson. 1990. Leafhoppers (Cicadellidae); a Bibliography, Generic Check-list and Index to the World Literature 1956-1985. Wallingford, $\mathrm{CAB}$ International Institute Entomology, IV+368p. 
RAKITOV, R.A. 1997. On differentiation of the cicadellid leg chaetotaxy (Homoptera: Auchenorrhyncha: Membracoidea). Russian Entomological Journal 6: 7-27.

WiLSON, M.R.; J.A. Turner \& S.H. McKamey. 2009. Sharpshooter leafhoppers of the world (Hemiptera: Cicadellidae subfamily Cicadellinae). Available online at: http://naturalhistory. museum wales.ac.uk/sharpshooters/home.php [Accessed: 25/IV/2011].
Young, D.A. 1968. Taxonomic study of the Cicadellinae (Homoptera: Cicadellidae), Part 1, Proconiini. Bulletin of the United States National Museum 261: 1-287.

Young, D.A. 1977. Taxonomic study of the Cicadellinae (Homoptera: Cicadellidae), Part 2, New World Cicadellini and the genus Cicadella. Technical Bulletin of the North Carolina Agricultural Experiment Station 239: 1-1135.

Submitted: 25.IV.2011; Accepted: 23.VI.2011.

Editorial responsibility: Gabriel L.F. Mejdalani 